\title{
Science/policy boundaries: a changing division of labour in Dutch expert policy advice.
}

\author{
Willem Halffman and Rob Hoppe \\ Policy Sciences, University of Twente, the Netherlands ${ }^{1}$ \\ (to appear in: Scientific Expertise and Political Decision Making, edited by Sabine Maasse \\ and Peter Weingart. Dordrecht: Kluwer, 2004)
}

\section{Describing science/policy boundaries}

The tasks science-based experts perform for policy are many. In the traditional set of instrumental tasks, experts provide factual information to policy makers, assess future policy outcomes, or determine effects of past policies. However, the practice of policy expertise is much more varied. Experts may criticise policy makers' problem definitions, redefine problems, reframe policy beliefs, point at unanticipated outcomes, suggest alternative strategies, interpret policy and provide critical reflection, or even mediate in controversies (Bal et al., 2002, MacRae and Whittington, 1997, Renn, 1995).

This does not imply that experts do or should do all of the above all the time. There is no universal list of experts' tasks. Policy makers may prefer to rely on their own knowledge, their own mediating skills, or their own ability at critical reflection. Especially in times of difficult political bargaining, 'critical reflection' is the last thing politicians want, especially from the experts. In other cases, the very status of the expert is at stake and actors may attempt to redefine what can be considered a matter of expertise and what a matter of policy. That is why we can analyse the relation between experts and policy makers as a complex and contested division of labour. This division of labour consists of a boundary that demarcates who can and cannot be considered an expert in various degrees, and articulates the coordination between actors who have come to be considered 'experts' and 'policy makers'. Such boundaries are the outcome of - and form the resources for - continuing boundary work, the further articulation, reproduction, or modification of this division of labour (Halffman, 2003, Gieryn, 1999, Gieryn, 1995, Shapin, 1992, Jasanoff, 1990).

Over time, patterns have developed in this division of labour, varying between countries and policy sectors. Some advice giving tasks come to be recognised as important, and some as the job to be fulfilled by experts exclusively. Accordingly, the process of providing expertise is organised in different formats, ranging from ad-hoc expert committees, consensus conferences, contract research, to even informal meetings in a personal network. Hence, practices of advice giving develop into institutions, i.e. more or less routinised patterns in which expertise and policy are demarcated and coordinated.

Governments have installed expert organisations for the specific purpose of advising policy. Such organisations develop a body of knowledge, formal and informal rules about how to provide advice, a more or less guaranteed budget, or a conception of what is and is not their business. Government departments have developed procedures for commissioning research, ranging from model contracts to informal routinised practices of commissioning expertise. Scientists also have developed institutions for expert advice giving, such as professional codes of conduct, networking platforms for meeting policy makers, or conceptions of what kind of public roles their profession should or should not play (Peters and Barker, 1993, Hoppe, 2002a).

Most of the descriptions of this institutionalisation of science/policy boundaries tend to homogenise their account in one of two ways. The first and static homogenised account

\footnotetext{
${ }^{1}$ The authors are grateful for information and suggestions from Arthur Petersen, Huub Dijstelbloem, W. van Honstede, Bert de Wit, Peter van der Knaap, Arno Korsten, Johan Melse, the participants in the 'Torentjesoverleg' (junior researcher seminar series of the 'Rethinking' programme), the editors of Yearbook, and the participants in the preparatory workshop for this volume.
} 
describes patterns in science/policy boundaries as matters of national style. Such accounts attempt to identify a typical pattern in a country, and possibly relate this to crucial historic events (such as the imposition of the Code Napoléon), or the development in key macro institutions (such as the legal system or the civil service). For example, the US is typified as having an adversarial style of expertise, which is then related to an adversarial legal system and majoritarian politics. Such typifications are strong at accounting for the mutual connectedness of the institutionalisation of expertise and policy, the co-production of science and policy, but tend to have difficulty in accounting for short-term changes in the organisation of expertise or for the diversity between policy sectors (Bakker and Van Waarden, 1999, Renn, 1995, Vogel, 1986, Brickman et al., 1985, Halffman, 2003).

The second and dynamic homogenising conceptualisation is that of the grand transition. Such accounts try to identify how science/policy boundaries are changing from one form to another, compensating for the static bias of the national style notion. For example, transition accounts will point at increased transparency and accountability of experts towards citizens, increasing possibilities of wider participation in the production and evaluation of expert knowledge claims. Similarly, binary notions such as mode 1/mode 2 science (Gibbons, 1994) or normal/post-normal science (Ravetz, 1999) point at such transitions. Once again, the account tends to homogeneity: one state of affairs leads to another in an encompassing grand narrative.

In this chapter, we argue that these homogenising accounts of science/policy boundaries fail to address the diversity of institutional patterns, as well as the wide-ranging ideological disagreements that form their backdrop. With very inductive empirical accounts of the development of public expertise in the Netherlands over the last decades, we will show how at least three patterns of science/policy boundaries can be identified: a corporatist, a neoliberal, and a deliberative pattern. In doing so, we want to acknowledge the importance of the connectedness of expert and political institutions of the national styles-approach, but, while acknowledging the importance of national macro-institutions, bring forward and make sense of the maelstrom of transitions in the organisation of public expertise. We will show that various patterns continue to exist next to each other in Dutch national expert institutions; that the tension between these patterns is loaded with ideological disagreement and contradiction; and that we find diverse processes of change rather than one transition.

\section{Corporatist expertise: the planning bureaus and the advisory councils}

In corporatist policy arrangements, a restricted set of what are considered a sector's main policy actors are formally accredited to participate in the policy arena. In various forms and with considerable variation over time, (neo-)corporatist modes of decision making have been strong in the Netherlands, especially in socio-economic policy. In these modes, the institutionalisation of expertise takes one of two typical forms. In the first form, the formally accredited actors mobilise their own expertise. In the more technical negotiations, actors may even be represented by experts. For example, a university professor may participate in a negotiation over health insurance benefits to represent the position of patients. We see this pattern strongest in the old system of Dutch national advisory councils. In the second form, the experts draw up the playing field for the corporatist negotiations. Experts then act as the linesmen of politics, indicating within which constraints actors can operate. Just like in the soccer game, they wave a flag whenever the negotiation game exceeds budgetary constraints or becomes unrealistic about next year's economic growth. This pattern can be found most clearly in the present position of Dutch planning bureaus.

To start with the former, the Dutch corporatist tradition of ruling by consensus among an elite of 'relevant actors' (the model of recognised employer organisations and unions expanded to other sectors of society) had led to a large number of sector-specific advisory councils. By 1976, there were 402 of them, providing platforms for negotiation and attempts to build sectoral consensus. Not all of these were strictly advisory, as some even had tasks in policy implementation or regulation. The unbridled expansion of advisory councils eventually became a policy issue itself, resulting in a long list of reports. Over a period of two decades, 
various reports advised how to reduce their number and create some order. Meanwhile, the advisory bodies themselves changed. Whereas an inventory of 1976 had counted a third of the membership of these councils as 'independent experts' (Wetenschappelijke Raad voor het Regeringsbeleid, 1977), by 1993 this had become two thirds (Oldersma, 2002). The participation of various groups in 'their' policy sector was increasingly taken over by experts representing their position.

This tendency to professionalise, the shift from interest representation to interestcum-knowledge representation, was eventually taken to a radical conclusion. At the initiative of the Ministry of the Interior, the debate resulted in two laws in 1997, one providing a new framework for advisory councils and one abolishing nearly all of the existing ones. After this radical reorganisation, there were only eleven major advisory councils left, next to about seven highly specialised ones. With the exception of one, the Social and Economic Council, all the advisory councils were now considered expert councils. They were to advise with knowledge rather than interests. Another key principle was that advisory councils were to break out of their policy-specific niches, ranging across policy sectors. Advisory boards were to become more general and less tied to the specific interests and perspectives of the traditional policy fields. However, given that these advisory councils resort under the responsibility of individual government departments and that some of them have very specific functions in policy, most advisory councils have remained sector-specific, although sectors have come to be defined somewhat wider than before. The logic of diverse government departments, each with their specific professional strongholds, style of operation, and sectoral networks, proved stronger than that of a legal reorganisation (Klink, 2000).

To introduce a second major development, the Dutch planning bureaus provide government departments with assessments of the state of affairs and of future developments in their policy sector and relate these to policy options. The term 'planning' is somewhat misleading. They hardly ever 'plan' in the sense of selecting goals and allocating means, but rather analyse and forecast. The planning bureaus' status in the Dutch polity is exceptionally commanding, to the degree that the environmental and especially the economic planning bureaus routinely assess likely outcomes of political parties' programmes prior to elections. ${ }^{2}$ Political parties who refuse to submit their programme to such an analysis find their position severely undermined. Even the presentation of an uncertified oppositional counter-budget in Parliament, as an alternative to the government's annual budget, can be a political liability (Centraal Planbureau, 2003a, Van den Berg et al., 1993). For purposes of political negotiation and bargaining, predictions of economic growth, budget shortages, or unemployment figures are in most cases accepted as true and unproblematic inputs for decision making. In addition, government is even legally required to consult planning bureaus at some points in the policy making process and in the annual budget cycle. As such, the planning bureaus occupy positions as obligatory passage points for Dutch politics that would be considered unacceptably technocratic in most other countries (Van den Bogaard, 1998).

By 2002, there were planning bureaus for economic policy (Central Planning Bureau, CPB, established 1947), social and cultural policy (Social and Cultural Planning Bureau, 1973), environment (the Netherlands Environmental Assessment Agency in the National Institute of Public Health and the Environment, RIVM, which received the 'planning bureau function' officially in 1996), and urban and regional planning (the Netherlands Institute for Spatial Research, ${ }^{3}$ lifted out of the Department of Spatial Planning in 2002). The casual use of the term 'planning bureau function' now suggests that planning bureaus are an entirely natural phenomenon, a logical part of policy making: the 'function' needs to be fulfilled. However, the planning bureaus followed only one particular model for organising expertise, that of the Central Planning Bureau. Its strong reputation for econometric modelling, high policy impact,

\footnotetext{
${ }^{2}$ Although referred to as 'calculating through the proposals', this is more than just a matter of calculation, as negotiation and personalised expertise is required to interpret proposals and conform them to model input parameters.

${ }^{3}$ Known as 'Spatial Planning Bureau'. Official Dutch translations stubbornly use 'spatial' to refer to urban and regional planning.
} 
and close ties with the Ministries of Economic Affairs and Finances brought other ministries to develop competing expert resources of their own for the departmental tug-of-war and formed an enviable status for other expert organisations.

With four official planning bureaus in place, there are many opportunities for tension. Advisory organisations, like professional organisations, survive by claiming specific areas of expertise or specific approaches that make them unique and worthy of collective funds in the ecology of knowledge (Abbott, 1988). Such strategising can take the form of competition, as different government departments pitch organisations and their reports against each other in the heat of political conflict. However, the planning bureaus seek their legitimation in 'independence', in a 'neutral', or at least 'third party' stance with respect to the political process. In the presentation of hard figures, open competition is a high-risk strategy. It could easily lead to deconstruction of facts and mutual undermining of authority. In recent years, the planning bureaus have tended towards a strategy of accommodation, seeking mutual coordination through consultation. One example is the Planning Office Directors Consultative Committee, an informal structure negotiating the relations between the planning bureaus, but also articulating what it means to be and act like a planning bureau (Overleg Directeuren Planbureaus, 1996, Wetenschappelijke Raad voor het Regeringsbeleid, 2001, Centraal Planbureau, 2003b).

The term 'independence' of the planning bureaus thus has a specific meaning: planning bureaus claim that blatant political influence will not alter their advice, even if unwelcome. However, 'independence' clearly has its limits, which is acknowledged by the planning bureaus themselves. For example, research agendas are coordinated with long-term policy perspectives and members of planning bureaus are often present as advisers at toplevel policy meetings (Centraal Planbureau, 2003c). In some cases, directors of the planning bureaus will even attend Cabinet meetings (Hoppe, 2002b). This is not surprising, as these are exactly the kinds of 'dependencies' that assure a productive cooperation between experts and policy makers. To enact 'independence' it needs to be articulated, specified in practices, rules, and institutional arrangements. Allowable dependencies need to be distinguished from unallowable ones; the organisation must be kept out of the vortex of mediated politics, and where it enters this vortex its image must be spun with care.

In the attempt to create independence, there is some preoccupation with the organisational status of planning bureaus. The 'closeness' to their respective government departments tends to be understood as a matter of organisational schematics. Over the last couple of years, the newly preferred organisational status for the planning bureaus has been that of an agency, formalising the arms length position of planning bureaus. One of the key issues is the diversification of clients, since agencies normally do not work for government alone, but are expected to raise some of their own money on the contract research market. Presently, in the case of the RIVM, these clients are explicitly not to include industry (unless if requested by a government department) and the common planning bureau protocol also states that "commercial research assignments are generally seen as a threat to the credibility / independence of the planning offices" (Overleg Directeuren Planbureaus, 1996, Rijksinstituut voor Volksgezondheid en Milieu, 2003).

These shifts thus represent ambivalent changes in the division of labour in corporatist patterns. Planning bureau assessments are not always received without objection and not all planning bureaus have achieved the status of the economic one, the CPB. However, the degree of acceptance of assessments as reliable, independent, and for all practical purposes 'true', is remarkable. In spite of the fact that planning bureaus are seen as resources by various government departments, positioning them as ways to promote their policy agenda in their mutual competition, planning bureaus' identification of expected policy outcomes tend to be widely accepted, thus creating the space within which bargaining is possible. Similarly, the advisory councils have moved from a logic of interest-cum-knowledge representation to one of representation of the issues and the state of 'relevant' knowledge. This does not mean that the restriction of policy access to the major actors, typical for corporatist decisionmaking, has disappeared. Rather, experts have been repositioned, providing especially the executive with stronger leverage to break through corporatist deadlocks (Hemerijck, 1994). 
Goals and preferences may vary, but in a political system that is highly diverse, with complicated coalition governments, having stern arbiters that judge the outcomes of proposed policies reduces the complexity of negotiations. In a fluctuating multi-party system where results of elections are always politically ambiguous and with strong tendencies to pacify conflict (rather than to humiliatingly defeat an opponent who could be a needed ally tomorrow), experts are welcomed as linesmen of politics. Especially in the case of planning bureaus, their verdict is accepted even if this means that some policy alternatives are blocked off by assumptions in a computer model that are technical and hard to question.

\section{Neo-liberal patterns in public expertise}

The development towards a (neo-)corporatist linesman of politics in Dutch expertise is only one. Other developments point in the direction of a growing importance of a neo-liberal pattern for the organisation of the science/policy boundary. Typical of this pattern are the small state philosophy, leading to the 'externalisation' of expertise out of government departments, and a strong emphasis on the market to coordinate expert resources. We already indicated that most planning bureaus have moved towards agency status. In addition, the erosion of the old corporatist advisory system at least ran parallel to the neo-liberal rejection of corporatist policy arrangements, where state and society are seen as unacceptably colluded. There are two more indications that a neo-liberal pattern of public expertise is becoming more important in the Netherlands: the radical externalisation of expertise at some ministries, and the growing contractualisation and commodification of expert knowledge.

Most government departments are entangled in a continuing struggle to find the most suitable position for expertise. While there is an increasing awareness of the importance of knowledge for successful policy making, and while concepts such as 'knowledge intensive administration', 'knowledge infrastructure', or 'evidence based policy' are increasingly popular among analysts (Beker et al., 2003, Paardekooper, 2003, Dijstelbloem and Schuyt, 2003, Kronje, 2003), it is by no means clear what this means for the organisation of the science/policy boundary. This struggle is a matter of both the internal departmental organisation and of external relations with expert organisations. It is in this context that neoliberal solutions have surfaced most radically.

First, is it preferable to have one research division in a department, or is research and knowledge to be managed within the various functional units of a department? The organisation of expertise in a department can have considerable consequences for the freedom sub-units may have to gather and supervise expertise. Distributed control over research may allow expertise to be fed into policy more directly, as long as the civil servants concerned manage the process well. A centralised research directorate, on the other hand, may be more apt at guaranteeing quality of research, at the potential cost of developing into an ivory tower. Various departments opt for different solutions here. For example, since about 1995, the ministry of Social Affairs and Employment toyed with the idea of a specialised research division. Proponents argued that it would lead to better and more shared knowledge. After much deliberation, a research division was indeed set up, only to be abolished again a year later. The ministry now focuses its knowledge management on permanent learning for its staff through an 'Academy', in correspondence with the 'lifelong learning' policy for the Dutch work force (Ministerie van Sociale Zaken en Werkgelegenheid, 2003). In contrast, the department of Traffic and Water Management has experimented with a research division since the early nineties, which has resulted in a special Directorate for Knowledge and Development (Ministerie van Verkeer en Waterstaat, 2003).

However, secondly, departments have struggled with the question to what extent expertise can be externalised into more or less autonomous agencies - or should be outsourced to consultancies or other research organisations, among which universities. Over the last decade, some departments have externalised expertise in a quite radical way. The form of externalisation has varied and not all departments have followed suit. The department of Spatial Planning has kept part of its division of planning, but has created the Spatial Planning Bureau. The department of the environment continues to grant more autonomy to 
the RIVM, first changing annual agreements on research to bi-annual ones, and eventually giving the institute agency status in January 2004.

Externalisation comes with specific problems, which lead to new coordinating institutions. The Ministry of Health, Welfare and Sports has virtually lost all its short-term influence over research, as the major research institutes under its responsibility work only with longer term research programmes (such as the Social and Cultural Planning Bureau and the health research resources of the Dutch national fund for scientific research) (Beker et al., 2003). In addition, this ministry has invested heavily in the development of independent 'knowledge centres'. This may lead to increased availability of knowledge in the policy sector, but most of these centres tend not to see government as their main client (see below). The Ministry of Agriculture, Nature and Food Quality has organised its expertise in a separate Expert Centre. The sole client of this Centre is the Ministry and it is to prepare and evaluate policy, as well as critically follow it. Nevertheless, the Ministry has its own department of Science and Knowledge Transfer, which is to operate as a knowledge broker (Expertisecentrum LNV, 2003a, De Wit, 2003, Ministerie van Landbouw, 2003, Expertisecentrum LNV, 2003b). The creation of such a knowledge broker seems typical. An increased distance may generate a stronger resource for building legitimacy, claiming 'independence' of expertise, it also creates a gap between immediate policy needs and the agenda of professional researchers. This induces complex negotiations over mutual relations and degrees of control over research agendas.

There may not be no single dominant pattern in the organisation of expertise within departments or in the degree of externalisation of research, but to the extent that research is externalised, there does seem to be a new development of complex and increasingly formalised negotiations over research projects and programmes. From the perspective of researchers, this development can be seen more clearly. Dutch government departments tend to keep an active role in the oversight of commissioned research. For example, the use of advisory committees has become standard practice. These committees are typically comprised of civil servants with some expertise in the matter at hand, as well as experts, usually sympathetic to the project. Advisory committees are consulted over the problem formulation at the beginning of a project, over the progress of projects, and over the end results. Careful selection of an advisory committee is acknowledged as a key instrument for maintaining control over a research project and for guaranteeing that the results will be of use for policy. In combination with financiers claiming ownership over reports and with disclosure clauses, government departments can exert considerable influence over the formulation of published reports and over the timing of their publication. In two recent cases that made the national newspapers, government departments used these instruments to prevent discussion of research results among scientists, rewrite conclusions or recommendations, or delay publication of unwelcome news (Ramdharie and Trommelen, 2003, Schreuder, 2003).

Who gets commissioned? Although there are only very rough indicators of how government departments spend their research resources, it does seem clear that universities are slowly slipping out of policy makers' favour, at least with national civil servants looking for policy advice. This follows the image portrayed by civil servants that departments presently favour either the authority of an established planning bureau or the convenience of a consultant - although universities are still good enough for $€ 156$ million's worth of commissions every year. In many cases, policy makers see academic researchers as unpredictable, over-principled and as refusing to stick to the policy problem at hand. Especially in an instrumental approach to researchers as fact-finders, consultants may provide more suitable avenues. From their perspective, some Dutch social scientists have complained that the grip on commissioned research has become too tight, sometimes verging on manipulation (Köbben and Tromp, 1999, Sociaal Wetenschappelijke Raad, 2000).

The amount of research government commissions to universities is relatively small in relation to their total research funds. The $€ 156$ million come out of $€ 2.278$ million in 2000 (Centraal Bureau voor de Statistiek, 2003). Nevertheless, with 7\%, this is still considerable and especially so for the social sciences and the unknown share they manage to obtain from it. In the second half of the nineties, university budgets have stagnated. Many social sciences, 
such as sociology, have been faced with reduced numbers of students, partly for demographic reasons ${ }^{4}$ and partly because of the popularity of new programmes such as communication studies. Contract research may offer some extra oxygen for research groups. However, either at the initiative of individual researchers or of universities themselves, much of the most profitable research has been organised outside of the restrictive corset of university organisations, of academic peer pressure, and of civil servants' employment regulations which still protect academics. Nevertheless, in the case of the social sciences, government is the main and sometimes the only client. Even though universities may no longer be as important to civil servants for advice, civil servants have become all the more important to academic social scientists looking for extra funding.

Here too, we see commodification combined with a need for new forms of coordination. If there is a general line in the development of how government departments gather expertise, it is that of contractualisation: relations have become increasingly formalised and legalised. The control practices around commissioned research have refined, as in the practice of setting up advisory committees. In addition, some departments have developed guidelines on how civil servants should set up commissioned research, often accompanied by sample contracts and detailed rules. Even the relation between departments and their research institutes now has taken a contractual turn in which agreements are made on research programmes and targets. The internationalisation of the market of expertise and the increased competition between sources of expertise are likely to drive this development further. The contractualisation of research supports civil servants in setting up advisory relations with a wider range of researchers, even researchers or consultants who are not familiar. In spite of such advantages, the hidden transaction costs are considerable, for example in the form of legal overhead, over-instrumentalised knowledge, problematic accumulation of knowledge over time, or of new institutions to deal with newly produced problems of science/policy coordination.

\section{Shifts towards deliberative patterns of organising public expertise}

In deliberative conceptions of democracy, public reasoning and discourse are seen as crucial aspects of politics. Therefore, we call a deliberative pattern of public expertise all those forms of organising the science/policy boundary that position expertise as a collective resource in public debate, wherever this takes place (parliament, sectoral forums, media). The pattern is frequently connected with discourses of public participation, the importance of experiential knowledge, public accessibility of knowledge, and reflexive awareness of the possibilities and limitations of expertise (Hajer and Wagenaar, 2003), thus contrasted with the restrictive nature of corporatist structures and the primacy for strictly representative democracy. We find the pattern most clearly in the experiments with interactive expert decision making stimulated by the Rathenau institute, the new phenomenon of 'knowledge centres', the improved selfunderstanding of public expert organisations, and - much more ambivalently - in the expanded expert resources of the Dutch parliament.

Traditional corporatist patterns of expertise to a certain extent did take into account opposing views in matters of expert knowledge. However, these patterns operated around relatively rigid corporatist channels of representation. The typical new issues of the risk society create new collectives, for which corporatist models prove insufficiently flexible (Beck, 1992 (1986)). For example, the initial attempts at regulatory negotiation and corporatist mediation in environmental issues, with the department of the environment stimulating the development of environmental groups through subsidies and the construction of statutory advisory boards in the eighties, gave way to new models in the nineties. This included government addressing societal actors directly, environmental groups negotiating with individual companies, or the construction of non-governmental regulatory bodies, such as for eco-labelling of food. In this setting, it is never a priori clear where relevant expertise

\footnotetext{
${ }^{4}$ In 1988, there were 256 thousand 18-year olds, the age at which Dutch students normally enter higher education. Presently, the number is 184 thousand (Centraal Bureau voor de Statistiek, 2003).
} 
will come from. New actors appear around new policy issues, bringing their own knowledge or their own concerns about how policy expertise is framed.

A key actor behind new ways of handling expert knowledge in controversial issues that defied traditional policy making, was the Rathenau Institute. In its attempts to find ways out of the conundrums of 'impact' type of technology assessment and to clarify its position towards government, the Institute started to experiment with new forms of bringing experts, citizens, stakeholders and policy makers together. It copied elements of the Danish consensus conferences or of American citizen juries, but also thoroughly stimulated the innovation of interactive and constructive technology assessment. The methodology developed by the institute is slowly finding its way to other organisations, for example in transition management aiming for sustainable technology (Van Est et al., 2002).

Another interesting example of the deliberative pattern of organising expertise is the emergence of 'knowledge centres', since about 1998. Although quite a few research institutes have simply relabelled themselves to catch the buzz word, the new knowledge centres claim to be qualitatively different. They claim to make knowledge more available for policy use, either by integrating knowledge, simply accumulating knowledge, or by performing a role as knowledge broker. Knowledge centres are seen as facilitators of a collective and public learning process, targeted at practitioners in general, rather than governmental policy makers in particular (Beemer and Den Boer, 2003). Their organisational form ranges from merely a portal web site, run by a handful of people, to the research facilities of an entire university (Wageningen). There are currently about 115 knowledge centres, largely funded publicly (Ketting, 2002). Knowledge centres generally organise themselves around policy fields or specific policy issues, rather than around the traditional definitions of research fields or disciplines. For example, there are knowledge centres for sustainable building (Nationaal Dubo Centrum, 2003) or urban policy (KEI Kenniscentrum Stedelijke Vernieuwing, 2003, Kenniscentrum Grote Steden, 2003). Especially the Ministry of Health, Welfare and Sport has actively supported the creation of knowledge centres, leading to a boom in this area.

What is new about the knowledge centres is not so much the claim of improved knowledge transfer, but their post-professional positioning, outside of those major strongholds of disciplines, universities, as well as established research institutes. This means knowledge centres can - in principle - operate across research fields and professional jurisdictions, integrating knowledge on an issue-basis in various forms of inter-disciplinarity. For example, the Knowledge Centre for Large Cities is setting up initiatives cutting across the division of labour between the social and physical aspects of urban planning (Kenniscentrum Grote Steden, 2003).

Evidently, this raises questions about quality assurance. Professionalised knowledge may have the bad reputation of becoming boxed-in and even self-referential (e.g. Cole, 1998), but professions also provide a platform for quality standards. Especially the smaller knowledge centres seem to rely blindly on the professional standards of their suppliers of knowledge. They stress the very low threshold access to easily digestible bits of information, whereby such complex problems of knowledge uncertainty or problem framing run the risk of being swept under the carpet. To be sure, there is attention for such problems in the larger knowledge centres, but most knowledge centres have to legitimate their existence by providing ready-made knowledge for policy, if need be at the expense of complication (Janssen and Schouw, 2003). Knowledge centres may be useful for policy makers as a means to break through the iron triangles of corporatists structures, but they are also at risk of becoming an excessively instrumental and under-critical, but cheap resource for policy makers, which even lend themselves to token policy making (Beemer and Den Boer, 2003).

Another striking development in the world of Dutch expertise for policy is an increased level of reflexivity among some of the major expert organisations. Major advisory organisations have produced reports touching on the status of knowledge in the policy process (in most cases their own knowledge), or have published (self)evaluations. Reflection on policy research has a tradition in the Netherlands, especially as supported by the 'sector councils'. These councils of researchers, policy makers, and societal representatives traditionally reported on strategic goals for research in agriculture, health, nature and 
environment, and development. However, the focus on strategic research goals and recommendations on how to achieve them, has now been complemented with reflection on how this research is to relate to policy and how expertise is to be organised (Hoppe and Huijs, 2003, Raad voor Ruimtelijk Milieu- en NatuurOnderzoek, 2000, In't Veld, 2000). In this new frame of thinking, the sector councils too see themselves increasingly as (also) knowledge brokers.

Several other examples stand out. The Scientific Council for Government Policy has produced several reports reflecting on expert policy advice, such as on uncertainty in environmental expertise (Wetenschappelijke Raad voor het Regeringsbeleid, 1994), or recently on ICT and policy knowledge (Wetenschappelijke Raad voor het Regeringsbeleid, 2002) or the public role of knowledge (Dijstelbloem and Schuyt, 2002, Dijstelbloem and Schuyt, 2003). Uncertainty in expertise for policy is a theme that is receiving increasing attention, especially in environmental issues. Since about 1997, uncertainty of expertise has become a topic at the RIVM, exacerbated by a media scandal in 1999 about the alleged overreliance of the RIVM on computer models over actual measurements. Since then, RIVM has continued to organise (external) reflection of how it handles uncertainty and how it could construct better uncertainty management, some of which we are currently involved in (Van Asselt et al., 2001, Rijksinstituut voor Volksgezondheid en Milieu/Milieu- en NatuurPlanbureau, 2003). Also noteworthy is the increased use of external evaluation reports as an occasion for active reflection on the operation of advisory institutes. Unlike a decade ago, evaluation reports are now available for several advisory bodies.

The increased reflexivity has come with a more relaxed attitude about allowing outsiders a glimpse into the back regions of expert knowledge production, glimpses which would have been considered inappropriate and undermining only ten years ago. However, the development is not shared everywhere. One reason is the lingering fear of making visible some of the contingent aspects of the construction of expertise, hence undermining credibility of expert advice. There are bureaucratic survival issues also. Even the suggestion of a negative evaluation report can have severe consequences for the continuation of advisory institutes, especially if their legitimacy was not entirely solid or in times of budget cuts.

A more ambivalent, but interesting development is the expansion of the expert resources of the Dutch Parliament. In Dutch government, the centre of gravity in expertise lies with the ministries. The most important among them have direct access to major research institutes and expert advisory boards, neatly organised around their respective jurisdictions. In contrast, the Parliamentary resources were traditionally limited to a small library staff and modest administrative support. Even the larger political parties can only support research bureaus with about half a dozen researchers. Expanding Parliamentary expert resources was seen as a wasteful duplication of governmental bureaucracy and a source of instability for the detailed political agreements of the executive that form the basis of coalition governments. As a rule, MPs hence have to rely on Ministers for information, through oral and written questions in Parliament, or through motions. To the extent that the traditions of Dutch Parliament provide research resources, they take the form of Parliamentary investigations, executed by ad-hoc Parliamentary committees; or budgetary oversight, supported by reports from the feared and very old Court of Audit (Algemene Rekenkamer).

In principle, Parliament is the focal point of public deliberation and hence a key place to look for deliberative expertise. Over the last decade, the position of Parliament in matters of expert knowledge has been reinforced. In existing institutions, there has been a more intensive use of Parliamentary investigations and an important shift in the Court of Audit from budgetary oversight to 'effectiveness' of policy - and hence substantive policy evaluation. In addition, some newer institutions have appeared on the Parliamentary horizon. During the first half of the nineties, the Rathenau Institute, the Dutch organisation for technology assessment, came to consider Parliament as its main client, a view that was formalised in a new legal mandate in 1994. Recently, the Rathenau Institute has supported some of the research activities of Parliament, for example by providing expertise for the organisation of Parliamentary hearings, but also for Parliament's new Research and Verification Bureau. This was installed in 2002 and is to support Parliament both with the 
'verification' of expert reports offered by ministries, and with the commissioning of Parliamentary research, whether in the context of Parliamentary investigations or motions calling for research.

The list of expert organisations Parliament could consult is open-ended, as long as resources are available. Since the reorganisation of advisory councils of 1997, legal provisions were made for Parliament to ask any of the remaining advisory councils for advice directly. Remarkably, an exception is made for the planning bureaus. Without an official mandate, individual members of the planning bureaus are not even allowed to talk to MPs, as stipulated in the national civil service regulations. However, various Ministers have had their own views on the issue, sometimes even relaxing the reigns on direct Parliamentary contacts. ${ }^{5}$

So far, Parliament has made limited use of its new capacities to gather expert knowledge. With the support of the Research and Verification Bureau, eight research initiatives were undertaken since 2001, mostly through private consultants (Tweede Kamer, 2002, Tweede Kamer, 2003). In general, Parliament sticks to the more familiar instrument of Parliamentary investigation committees, especially for addressing problems perceived by a majority as particularly pressing. Its style of dealing with expertise so far has rarely followed the logic of deliberative expertise, where experts and policy makers communicate on a more equal footing. With the possible exception of a few parliamentary hearings and some minor experiments, the logic of representative government that makes use of instrumental expertise has dominated.

Here too, as with the other patterns, the pattern of deliberative expertise is therefore ambivalent and not without flaws. The new knowledge brokers in the knowledge centres may aim to improve public deliberation, but the risk of under-critical, unreflexive, and uncertified knowledge is clearly present. The reflection of large public expert organisations holds some potential for approaches to public deliberation of expert issues, but moves in this direction are very hesitant. Parliament seems to have an institutional gap to take a more active role in knowledge intensive policy issues, but leaves its instruments under-used or uses them in instrumental ways.

\section{Changes in the polity, changes in scientific advice}

Changes in the expertise/policy making boundaries in the Netherlands over the last decade have been complex. New organisations, new formats for expertise, and new policy issues have emerged in new arrangements, while old ones have not necessarily disappeared. We have pointed at such salient developments as the restructuring of the advisory councils into a small set of expert councils; the gradual expansion of planning bureaus; the externalisation of departmental expertise; the contractualisation and commodification of expertise; the modest expansion of parliamentary expert resources; the growth of 'knowledge centres'; and the increasing reflexivity of expert organisations.

We have ordered these developments in three competing patterns for the organisation of the science/policy boundary. In corporatist patterns, where a limited set of actors is formally accredited to participate in decision making as representatives of societal interests, experts either participate to represent knowledge considered relevant in a corporatist style advocacy behind the scenes, or guard the boundaries of the playing field for corporatist negotiations. In the Netherlands, we have observed a shift from the first pattern to the latter. However, next to these, new patterns are becoming stronger. One is a neo-liberal pattern, which removes expertise from the state and its negotiation structures and uses the market as a means to coordinate expertise. The pattern does not come without a price. Transaction costs tend to be high, in the form of increasingly complex contractualisation of professional work,

\footnotetext{
${ }^{5}$ One last addition is the recent announcement of the installation of a council of economic advisers. Three top economists are to provide Parliament with countervailing analytic power against the weight of the Central Planning Bureau. It is as yet entirely unclear how this council will operate, but previous experiences with a similar council in the UK are not very reassuring Collins, H. M. and Pinch, T. J. (1998), The Golem at Large: What You Should Know About Science (2nd edition), Cambridge: Cambridge University Press..
} 
which tended to rely heavily on personal trust and negotiation. In addition, there are risks of undermining accumulation of knowledge over time, as past knowledge is stored in volatile consultancy firms and untraceable grey literature, and of instrumentalising research and hence undermining quality. Last, we see a number of these developments as examples of a deliberative pattern in the science/policy boundary, where public decision making is predominantly seen as a matter of collective reasoning and argumentation, stressing large degrees of participation in matters of interest as well as knowledge. In this pattern, the inclusion of the plurality of sources of knowledge is stressed, leading to new ways of integrating heterogeneous expertise, under increasing reflexive awareness of its limitations. There are various ways in which this pattern can be played out, for example ranging from stronger expert resources for parliamentary debate to policy sector knowledge brokers.

Similar shifts can be found in other countries. For example, in Germany an expansion of parliamentary expert resources has also been noted (see Brown, Lentsch and Weingart, this volume), as well as a similarly hesitating acknowledgement of the plurality and distributed nature of knowledge (Heinrichs, 2002). Points of comparison can also be found in other European countries (Glynn et al., 2001). Such shifts reshuffle the division of labour between experts and policy makers. For example, handling and interpreting uncertainties is a task for the experts where they are the linesmen of politics; but for the policy maker where expertise is hired on the market on an ad-hoc basis; and one that is typically shared in collective reflection in deliberative patterns of organising expertise. Similarly, experts taking up tasks of conflict mediation is seen as perfectly legitimate in the deliberative pattern, but something to be avoided by the corporatist linesmen.

Our objective here is not to show how the Netherlands is unique or different from other countries, but to show that within a country such as the Netherlands, various patterns for organising science/policy boundaries are competing with each other. We have intentionally labelled these patterns with terms that allude to political connotations, both because of how the organisation of expertise is co-constructed with the organisation of political decision making, and because we want to point at the ideological connotations of these patterns. Rather than a grand transition from one mode of public expertise to another, or some essential national style, driven by a handful of constitutional prime movers, we see multiple patterns in tension and competition with each other. These patterns conflict and vie for dominance, argue against each other, and hence partly develop in response to each other. Such is the make-up of modern polities and the fact that we find similar tensions in the organisation of expertise, only shows how much expertise has become embedded in these polities. 


\section{References}

Abbott, A. (1988), The system of professions: an essay on the division of expert labour, Chicago, Ill.: University of Chicago Press.

Van Asselt, M. B. A., Langendonck, R., Asten, F. v., Giessen, A. v. d., Janssen, P. H. M., Heuberger, P. S. C. and Geuskens, I. (2001), Uncertainty and RIVM's environmental outlooks, Bilthoven: RIVM, report 550002001.

Bakker, W. and Van Waarden, F. (eds), (1999), Ruimte rond regels: stijlen van regulering en beleidsuitvoering vergeleken, Amsterdam: Boom.

Bal, R., Bijker, W. and Hendriks, R. (2002), Paradox van Wetenschappelijk Gezag: over de maatschappelijke invloed van adviezen van de Gezondheidsraad, The Hague: Gezondheidsraad.

Beck, U. (1992 (1986)), The Risk Society: Towards a New Modernity, London: Sage.

Beemer, F. A. and Den Boer, M. C. (2003), 'Heeft de keizer kleren aan? Kenniscentra in het publieke domein', Bestuurskunde, 12, 4: 170-177.

Beker, M., Ooijens, M. and De Gier, E. (2003), Bewijs van goed beleid: naar een betere verhouding tussen wetenschap en sociaal beleid in Nederland, Amsterdam: SISWO, Working Paper.

Brickman, R., Jasanoff, S. and Ilgen, T. (1985), Controlling Chemicals: the Politics of Regulating Chemicals in Europe and the United States, Ithaca, NY: Cornell University Press.

Centraal Bureau voor de Statistiek (2003), Kennis en economie 2002: onderzoek en innovatie in Nederland, Voorburg: Centraal Bureau voor de Statistiek, K-300.

Centraal Planbureau (2003a), Charting choices 2003-2006, economic effects of eight election platforms, The Hague: Centraal Planbureau, report no. 19.

Centraal Planbureau (2003b), CPB website [Internet] Available from: $<\mathrm{http}: / / w w w . c p b . n l>$ [Accessed October 2003].

Centraal Planbureau (2003c), Through the Looking Glass: A Self-assessment of CPB Netherlands Bureau for Economic Policy Analysis, The Hague: CPB.

Cole, S. A. (1998), 'Witnessing Identification: Latent Fingerprinting Evidence and Expert Knowledge', Social Studies of Science, 28, 5: 687-713.

Collins, H. M. and Pinch, T. J. (1998), The Golem at Large: What You Should Know About Science (2nd edition), Cambridge: Cambridge University Press.

Van den Berg, H., Both, G. and Basset, P. (eds), (1993), Het Centraal Planbureau in Politieke Zaken, Amsterdam: Wetenschappelijke Bureau Groen Links.

Van den Bogaard, A. (1998), 'Configuring the economy: the emergence of a modelling practice in the Netherlands, 1920-1955', Doctoral dissertation, University of Amsterdam.

Dijstelbloem, H. and Schuyt, C. J. M. (2002), De publieke dimensie van kennis, Den Haag: Wetenschappelijke Raad voor het Regeringsbeleid, Sdu Uitgevers, Voorstudies en achtergronden V110.

Dijstelbloem, H. and Schuyt, C. J. M. (2003), 'Kennismaken: nieuw overheidsbeleid voor de kennissamenleving', Bestuurskunde, 12, 4: 152-159.

Van Est, R., Van Eijndhoven, J., Aarts, W. and Loeber, A. (2002), 'The Netherlands: seeking to involve wider publics in technology assessment', in Joss, S. and Bllucci, S. (eds), Participatory technology assessment: European perspectives, London: Centre for the Study of Democracy.

Expertisecentrum LNV (2003a), Jaarverslag Expertisecentrum LNV, Ede: Expertisecentrum LNV, EC-LNV nr. 2003/194.

Expertisecentrum LNV (2003b), Website Expertisecentrum LNV [Internet] Available from: $<$ http://www.minlnv.nl//nv/algemeen/eclnv/> [Accessed November 2003].

Gibbons, M. (1994), The new production of knowledge: the dynamics of science and research in contemporary societies, London: Sage. 
Gieryn, T. (1995), 'Boundaries of Science', in Jasanoff, S., Markle, G. E., Petersen, L. C. and Pinch, T. J. (eds), Handbook of Science and Technology Studies, Thousand Oaks: Sage, pp. 293-443.

Gieryn, T. (1999), Cultural Boundaries of Science: Credibility on the line, Chicago: Chicago University Press.

Glynn, S., Flanagan, K., Keenan, M. and Ibarreta, D. (2001), Science and Governance: describing and typifying the scientific advice structure in the policy making process a multi-national study, Seville: Joint Research Centre, Institute for Prospective Technological Studies, European Commission, EUR 19830 EN.

Hajer, M. and Wagenaar, H. (2003), Deliberative Policy Analysis: Understanding Governance in the Network Society, Cambridge: Cambridge University Press.

Halffman, W. (2003), 'Boundaries of Regulatory Science: Eco/toxicology and aquatic hazards of chemicals in the US, England, and the Netherlands, 1970-1995', doctoral thesis, University of Amsterdam.

Heinrichs, H. (2002), Politikberatung in de Wissensgesellschaft: Eine analyse umweltpolitischer Beratungssysteme, Wiesbaden: Deutscher Universitäts-Verlag.

Hemerijck, A. C. (1994), 'Hardnekkigheid van corporatistisch beleid in Nederland', Beleid \& Maatschappij, 21, 1-2: 23-47.

Hoppe, R. (2002a), 'Rethinking the puzzles of the science-policy nexus: Boundary traffic, boundary work and the mutual transgression between STS and Policy Studies'. Paper presented at EASST 2002 Responsibility under Uncertainty, York, 31 July - 3 August $2002 \mathrm{a}$.

Hoppe, R. (2002b), Van flipperkast naar grensverkeer: veranderende visies op de relatie tussen wetenschap en beleid, The Hague: Adviesraad voor het Wetenschaps- en Technologiebeleid, AWT achtergrondstudie 25.

Hoppe, R. and Huijs, S. (2003), Werk op de grens tussen wetenschap en beleid: paradoxen en dilemma's, Den Haag: RMNO, RMNO publicatie 157.

In't Veld, R. (ed.), (2000), Willens en wetens, Utrecht: RMNO/Lemma.

Janssen, J. and Schouw, G. (2003), 'Verdiepen, Verbinden, Versterken: Het Kenniscentrum Grote Steden in Actie.', Bestuurskunde, 12, 4: 178-189.

Jasanoff, S. (1990), The Fifth Branch: Science Advisers as Policy Makers, Cambridge, Mass.: Harvard University Press.

KEI Kenniscentrum Stedelijke Vernieuwing (2003), KEI website [Internet] Available from: $<\mathrm{http}: / /$ www.kei-centrum.nl/ $>$ [Accessed October 2003].

Kenniscentrum Grote Steden (2003), Website Kenniscentrum Grote Steden [Internet] Available from: $<$ http://www.kenniscentrumgrotesteden.nl $>$ [Accessed 22 October 2003].

Ketting, E. (2002), Kenniscentra in Nederland, Den Haag: Sociaal Cultureel Planbureau, SCP werkdocument 88.

Klink, E. (2000), 'Pleitbezorgers en Policy Windows: De institutionalisering van de integratie van emancipatie-aspecten in het nieuwe adviesstelsel', doctoraal scriptie, Universiteit Leiden.

Köbben, A. and Tromp, H. (1999), De onwelkome boodschap: of hoe de vrijheid van wetenschap bedreigd wordt, Amsterdam: Jan Mets.

Kronje, G. (2003), Overheid, Wetenschap en Toekomstverkenningen, The Hague: Wetenschappelijke Raad voor het Regeringsbeleid, Werkdocumenten W130.

MacRae, D. J. and Whittington, D. (1997), Expert advice for policy choice: analysis and discourse, Washington DC: Georgetown University Press.

Ministerie van Landbouw, N. e. V. (2003), Website Ministerie LNV [Internet] Available from: $<$ http://www.minlnv.nl $>$ [Accessed November 2003].

Ministerie van Sociale Zaken en Werkgelegenheid (2003), Website Ministerie van Sociale en Werkgelegenheid [Internet] Available from: $<\mathrm{http} / / / \mathrm{www} . \mathrm{minszw} . \mathrm{nl}>$ [Accessed November 2003].

Ministerie van Verkeer en Waterstaat (2003), Website Verkeer en Waterstaat [Internet] Available from: $<$ http://www.verkeerenwaterstaat.nl $>$ [Accessed November 2003]. 
Nationaal Dubo Centrum (2003), Website Nationaal Dubo Centrum [Internet] Available from: $<$ http://www.dubo-centrum.nl $>$ [Accessed October 2003].

Oldersma, G. J. (2002), 'Adviescolleges', in Daalder, H., Koole, R. A., Becker, J. W. and Meer, F. M. v. d. (eds), Compendium voor politiek en samenleving in Nederland, Alphen a/d Rijn: Kluwer, pp. C1100.

Overleg Directeuren Planbureaus (1996), Protocol voor de planbureaufunctie van CPB, RIVM, RPD en SCP [Internet] Available from: $<$ http://www.cpb.nl/nl/general/protocol.html $>$ [Accessed October 2003].

Paardekooper, C. (2003), 'Kennisintensieve beleidsorganisaties', Bestuurskunde, 12, 4: 160 169.

Peters, B. G. and Barker, A. (1993), Advising West European Government: Inquiries, Expertise and Public Policy, Edinburgh: Edinburgh University Press.

Raad voor Ruimtelijk Milieu- en NatuurOnderzoek (2000), Andere sturing: andere kennis nodig?, Den Haag: RMNO.

Ramdharie, S. and Trommelen, J. (2003) Rapport kraakt relatie Suriname, pp. 1.

Ravetz, J. (1999), 'What is Post-Normal Science?', Futures, 31: 647-654.

Renn, O. (1995), 'Styles of using scientific expertise: A comparative framework', Science and Public Policy, 22, 3: 147-156.

Rijksinstituut voor Volksgezondheid en Milieu (2003), RIVM website [Internet] Available from: $<$ http://www.rivm.nl $>$ [Accessed October 2003].

Rijksinstituut voor Volksgezondheid en Milieu/Milieu- en NatuurPlanbureau (2003), Leidraad voor omgaan met onzekerheden, Bilthoven: RIVM/MNP.

Schreuder, A. (2003) "Spreekverbod ecologen", NRC Handelsblad, 13 October, p. 3.

Shapin, S. (1992), 'Discipline and Bounding: The history and sociology of science as seen through the externalism-internalism debate', History of Science, 30, 90: 333-369.

Sociaal Wetenschappelijke Raad (2000), 'Sociale wetenschappen en beleid: een spannende verhouding'. Paper presented at Lustrumconferentie SWR 1995-1999, Amsterdam2000.

Tweede Kamer (2002), Raming voor de Tweede Kamer in 2003 benodigde uitgaven, alsmede aanwijzing en raming van ontvangsten, draaiboek onderzoek (bijlage 3), Den Haag: Tweede Kamer, vergaderjaar 2001-2002, 28 336, nr. 8.

Tweede Kamer (2003), Website Onderzoeks- en Verificatie Bureau [Internet] Available from: $<$ http://www.tweede-

kamer.nl/organisatie/Onderzoeks_en_Verificatie_Bureau/index.jsp $>$ [Accessed October 2003].

Vogel, D. (1986), National Styles of Regulation: Environmental Policy in Great Britain and the United States, Ithaca, NY: Cornell University Press.

Wetenschappelijke Raad voor het Regeringsbeleid (1977), Overzicht externe adviesorganen van de centrale overheid, Den Haag: WRR, rapport nr. 11.

Wetenschappelijke Raad voor het Regeringsbeleid (1994), Duurzame risico's: een blijvend gegeven, The Hague: Sdu Uitgevers, Rapporten aan de regering nr.44.

Wetenschappelijke Raad voor het Regeringsbeleid (2001), Spiegel naar de Toekomst: Evaluatie van de WRR, Den Haag: Wetenschappelijke Raad voor het Regeringsbeleid.

Wetenschappelijke Raad voor het Regeringsbeleid (2002), Van Oude en Nieuwe Kennis: De gevolgen van ICT voor het kennisbeleid, The Hague: Sdu Uitgevers, Rapporten aan de regering nr. 61.

De Wit, B. (2003), Discoursen achter kennissystemen van departementen, memo, Den Haag. 